\title{
THE IMPROVEMENT OF THE COMPETENCY OF SCIENCE TEACHERS USING SCIENCE KIT: OPTIMIZING SCIENTIFIC LEARNING
}

\author{
Wahyuni Satria Dewi ${ }^{1 *}$, Mairizwan ${ }^{2}$, Renol Afrizon ${ }^{3}$, Hidayati ${ }^{4}$ \\ ${ }^{1,2,3,4}$ Department of Physics, FMIPA Universitas Negeri Padang, Indonesia \\ *Corresponding author: wahyunisatria@fmipa.unp.ac.id
}

\section{Article Info Article history:}

Received: January 11, 2021

Accepted: March 25, 2021

Published: March 31, 2021

\section{Keywords:}

Competence of science teachers

Science KIT

Scientific learning

\begin{abstract}
Based on observations and interviews with a science teacher at a junior high school in Pesisir Selatan Regency, it is known that there are still many science teachers who have not carried out practicum activities in scientific learning. Science kits are rarely used by teachers in science learning. The main reason is that the competence of science teachers in operating the science kit is still low. To improve the competence of science teachers in using KIT, it is very necessary to carry out activities to optimize the use of KIT for science teachers. The purpose of this study was to improve the competence of science teachers in using IPA KIT as a support for scientific learning. This type of research is a quasi-experimental design with a pretest-posttest using multiple choice test instruments at the beginning and at the end of the study. From the results of this study, it is known that there is an increase in the competence of science teachers in using science kits, with the percentage increase of $29.25 \%$.
\end{abstract}

\section{PENINGKATAN KOMPETENSI GURU IPA DALAM MENGGUNAKAN KIT IPA: OPTIMALISASI PEMBELAJARAN SAINTIFIK}

\section{Kata Kunci: \\ Kompetensi guru IPA \\ KIT IPA \\ Pembelajaran saintifik} \begin{abstract}
ABSTRAK
Berdasarkan observasi dan wawancara dengan seorang guru IPA SMP di Kabupaten Pesisir Selatan, diketahui masih banyak guru IPA yang belum melaksanakan kegiatan praktikum dalam pembelajaran IPA. Kit sains jarang digunakan oleh guru dalam pembelajaran sains. Penyebab utamanya adalah kompetensi guru IPA dalam mengoperasikan IPA masih rendah. Untuk meningkatkan kompetensi guru IPA dalam menggunakan KIT, sangat perlu dilakukan kegiatan optimalisasi penggunaan KIT bagi guru IPA. Tujuan penelitian ini adalah untuk meningkatkan kompetensi guru IPA dalam menggunakan IPA KIT sebagai penunjang pembelajaran saintifik. Jenis penelitian yang digunakan adalah quasi eksperimental design dengan pretest-posttest menggunakan instrumen tes pilihan ganda pada awal dan akhir penelitian. Dari hasil penelitian diketahui bahwa terdapat peningkatan kompetensi guru IPA dalam menggunakan perangkat IPA dengan persentase peningkatan sebesar $29,25 \%$.
\end{abstract}




\section{INTRODUCTION}

Learning is a system composed of various components that influence one another. Learning components include objectives, teaching materials, methods and media, evaluation, students and teachers. The teacher as one of the determinants of learning success, plays a very important role in designing the learning process including teaching materials, methods, and learning media to achieve the expected goals. For this reason, it is absolutely necessary to have a teacher who is creative, active, and has sufficient competence to prepare meaningful learning for students. Learning will be more meaningful if students experience what they learn by activating more senses than just listening to the teacher's explanation [1]. Incorporating experiences into the learning that students learn is one of the processes of gaining knowledge in science learning.

Philosophically, natural science is concerned with finding out about nature in a systematic manner [2]. Science is a collection of systematic theories, its application is generally limited to natural phenomena, born and develops through scientific methods such as observation and experimentation and demands scientific attitudes such as curiosity, openness, honesty, and so on [3]. Natural science is a branch of science that bases the scientific development of its knowledge. The application of the scientific approach in science learning in the 2013 curriculum is an affirmation of the scientific approach to learning. Learning with a scientific approach plays a major role in fostering the ability to think, work, and be scientific, and communicate as an important aspect of life skills [4]. Science learning in junior high schools should emphasize providing direct learning experiences through the use and development of process skills and scientific attitudes.

The scientific approach makes Natural Science learning more active and more enjoyable, students can construct their knowledge and skills through facts found in investigations in the real environment of students [5]. Science learning based on this scientific approach emphasizes the skills of students to observe, ask, reason, and communicate or present things learned from natural phenomena or direct experience [6]. Therefore, science learning should be carried out with practicum activities, because science learning is not only about mastering concepts, but also a fact-finding process, so that the knowledge gained by students becomes stronger in their memory. Practical activity is a way of presenting lessons by conducting experiments, which means that students carry out activities that include controlling variables, observation, involving comparisons or controls, and use of practicum tools [7].

In practicum activities, students observe directly and carry out their own experiments to prove the theory being studied. The results obtained from practicum activities make students prove the truth of a theory, not only receiving information from teachers and books. Practical activities can also enrich experiences, develop scientific attitudes, and this knowledge will last longer in the memory of students [8]. In the 2013 curriculum, the observation process through this practicum activity is further elaborated as one of the goals of Natural Science learning as stated in the Graduation Competency Standards.

In accordance with the Regulation of the Minister of National Education of the Republic of Indonesia Number 23 of 2006 concerning graduation competency standards for Primary and Secondary Education Units, the competency standards expected in science learning are that students can make observations with appropriate equipment, carry out experiments according to procedures, record observations and measurements in appropriate tables and charts, make conclusions and communicate the results verbally and in writing according to the evidence obtained [9]. To achieve this goal, the function of the laboratory should not only be for practicum activities but also as part of science learning activities. For this reason, the availability of good quality science laboratory equipment in 
sufficient numbers in schools is very important. In order to fulfill the need for junior high school science laboratory equipment, science equipment provided by the government includes: a) physics equipment consisting of mechanical kits, optical kits, electric and magnetic kits, heat and hydrostatic kits, as well as general physics tools, b) biological equipment which consists of a microscope, general tools, materials, models, and charts [10].

The reality found in schools is that the availability of a complete and good quality science kit has not been able to solve the problems in science learning. Science kits are rarely used by teachers in science learning. This is because the teacher's ability to recognize and use science kits is still lacking. Based on the results of Rosnita's research which explained that the results of direct observation of practicum activities showed that the overall skills of teachers in carrying out practicum using science kits were $64 \%$ or categorized in the moderate category [11]. Teachers rarely provide guidance to students when conducting scientific experiments, even though science kit props are already in school. This limited ability of teachers has an impact on the low ability of students to use science. Students are not able to connect natural phenomena in the surrounding environment with the science material that has been studied. For example, there are many electrical phenomena that occur in the lives of students that they have not been able to associate with science material. This is because students are not skilled or have never even experimented with science kit equipment.

Although the Ministry of Education and Culture of the Republic of Indonesia has expressed hopes for the application of a scientific approach to science learning by optimizing the use of science laboratory equipment such as science kits, the real conditions in schools do not match these expected conditions. From the observation activity at one of the junior high schools in Pesisir Selatan Regency, it was obtained a picture of the real problems faced by science teachers. First, the media science kit in the school has not been optimally utilized by the teacher for science learning. Teachers have not designed science learning by conducting experiments in the laboratory because of limited time and limited competence in using science kits. This limitation causes students to be unable to master the concept as a whole, because students do not directly apply the theory they get. Second, most science teachers still have difficulty writing student worksheets that fit the scientific approach.

The use of the media science kit, which was not optimal, is an encouragement for researchers to seek to optimize the use of the science kit to improve the competence of science teachers. In addition, the solution given to overcome this problem is to provide training on science learning with a scientific approach as well as debriefing on the preparation of a science student worksheet by applying a scientific approach. With this optimization it is hoped that it can increase the knowledge and skills of science teachers in using science kit teaching aids to support scientific learning in the classroom.

Science kit in Indonesian is called the IPA KIT (Kotak Instrumen Ilmu Pengetahuan Alam Terpadu/Integrated Natural Science Instrument Box) [12]. The science kit is a science learning media with an experimental method, where students can experiment by proving their own theories that have been learned through reading material. This teaching aid will be able to help students build science knowledge, because they are involved in a cycle of inquiry which is a replication of the approach used by scientists in building knowledge [13]. In addition, through the KIT IPA media, students can be more motivated to learn and gain their own experiences in building their knowledge. The existence of practicum activities as a support for scientific learning makes learning science more 
enjoyable and more memorable, because students are directly involved in the learning process.

The use of science kits is needed in science learning innovations that apply a scientific approach, so that learning becomes more attractive to students. This was made clear by Lewis et.al, who stated that a fast and practical way to innovate science learning to be more attractive to students was to use props (science kits) [13]. The functions of science teaching aids, among others, can activate communication and interaction between teachers and students, and between students and students; can stimulate the thoughts, feelings, attention, and willingness of students so as to provide a more meaningful learning experience; arouse students' desire and interest in learning; build the basics for learning development so that lessons are more attached to memory, and provide real experiences that can foster student independence [14] [15].

The importance of the role of the science kit in helping students to get real experiences from the scientific learning process requires teachers to utilize this tool more optimally. Based on this background, a study was conducted on activities to optimize the use of science kits to improve the competence of science teachers in Pesisir Selatan. The purpose of this study was to see the increase in the competence of science teachers in using kits for science practicum. The novelty of this research is that this research examines more deeply the activities carried out in order to optimize the role of teachers in using science kits through four stages of optimization workshop activities. In addition, this optimization also results in Student Worksheet products designed by teachers based on practicum activities with science kits.

\section{METHOD}

This type of research is quasi-experimental using a quantitative approach. Research with a quantitative approach means that research uses numbers in presenting data and analyzing data using statistical tests [16] [17]. Furthermore, Creswell stated that "quantitative research is an approach for testing objective theories by examining the relationship among variables. These variables, in turn, can be measured, typically on instruments, so that numbered data can be analyzed using statistical procedures [18]. The research design used was the pretest-posttest group only design [19]. A pretest is given to science teachers before optimization and posttest is given afterwards. Furthermore, these two test results were analyzed to determine the increase in the competence of science teachers in using the kit. The research procedure consists of four stages, namely: debriefing, science kit simulation, independent activities, and monitoring and evaluation, as shown in Figure 1.

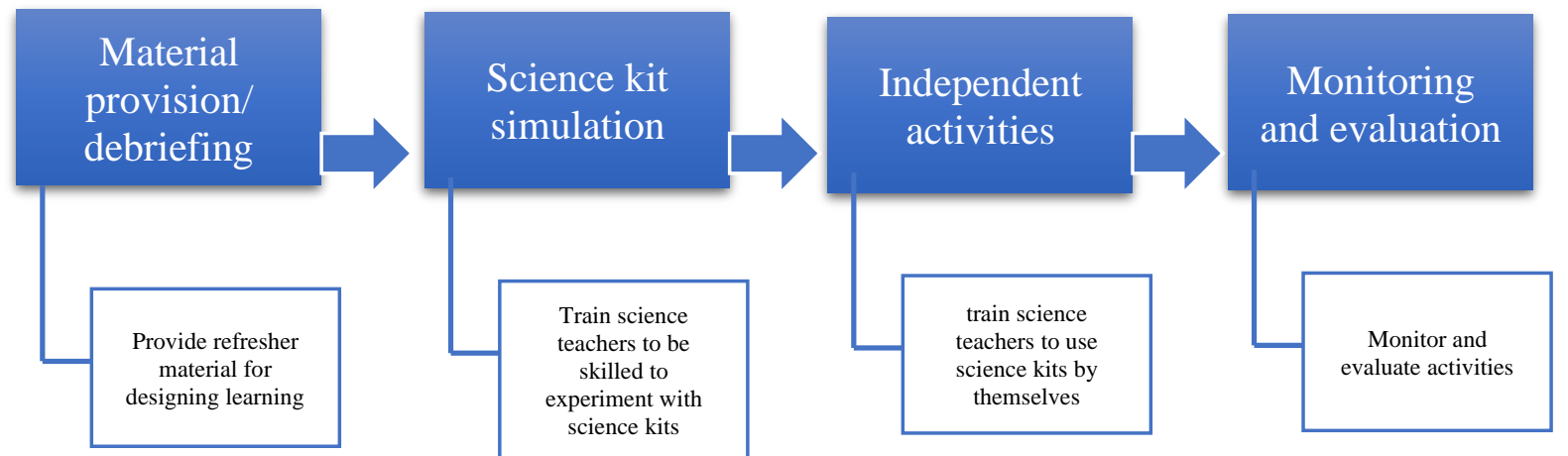

Figure 1. Research Procedure 
The activity of optimizing the use of this science kit is carried out in a structured and scheduled manner with several steps taken to solve the problems of the teachers. The implementation of the activity is divided into four stages as in Figure 1.The stages of research along with documentation of the implementation of each stage can be seen in Table 1.

Table 1. Activities

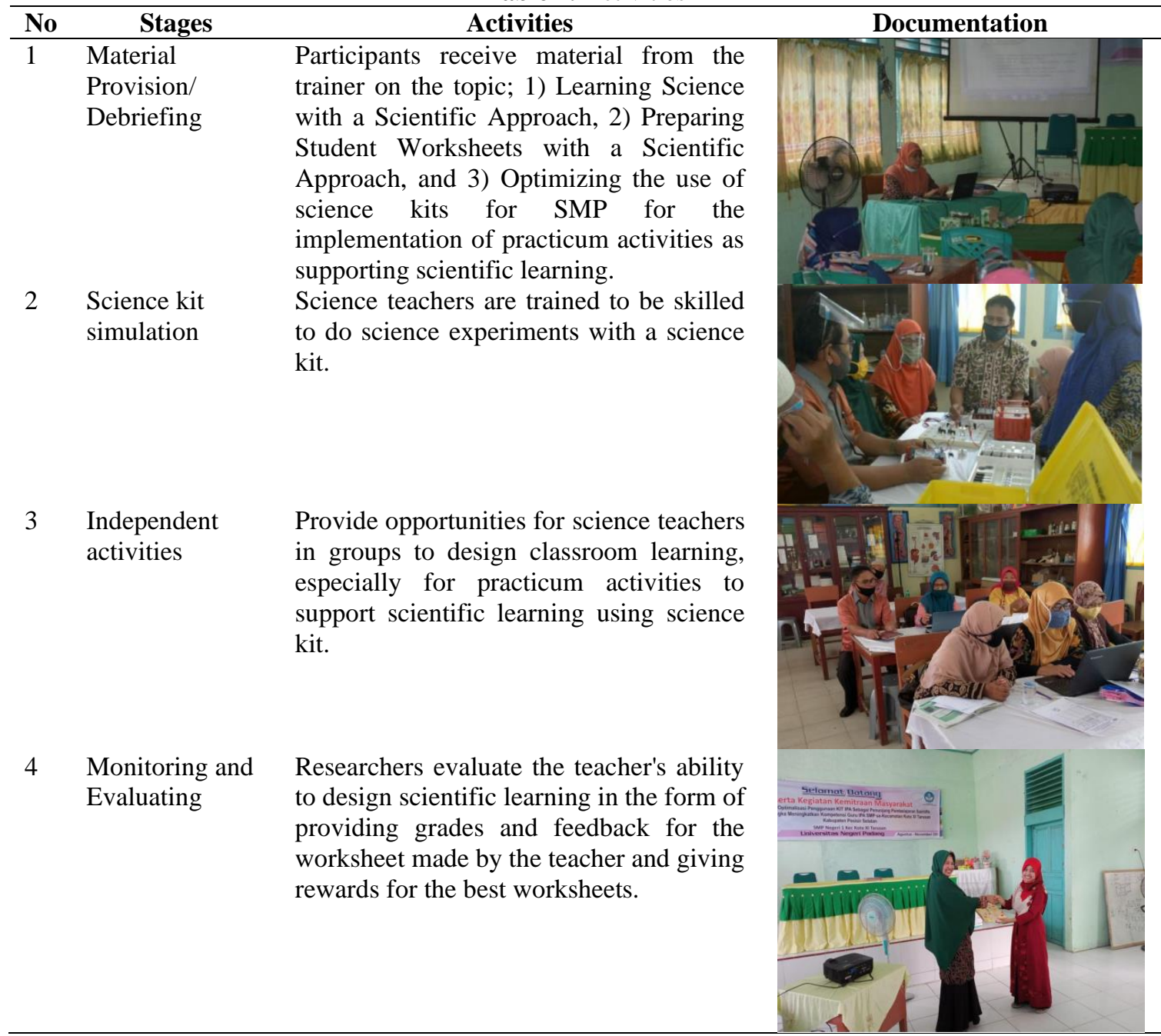

To obtain data on improving the competence of science teachers, a test instrument was used. The test in this study consisted of 20 pretest questions and 20 post-test questions in a multiple choice form. To get the results, the pretest and posttest questions are made different, but there are parallels between the two. The basis for the preparation of these test questions is based on increasing the competence of science teachers in understanding scientific learning and being skilled in using science kits. From the basis of competency improvement, question indicators are formulated in the form of a pretest and posttest question grid.

The population in this study were all junior high school science teachers who were members of the South Coastal science subject teacher association. Population is a generalization area consisting of objects, subjects that have certain qualities and characteristics determined by the researcher [20]. With the simple random sampling technique, 20 science teachers were chosen to represent all junior high schools in Pesisir Selatan Regency. The data obtained from the activity of optimizing the use of this sciencce 
kit is data on the mastery of science teachers in using science kits to support scientific learning. Furthermore, the data obtained from this study were analyzed using descriptive statistical analysis to describe the pretest and posttest data. The prerequisite test used in data analysis is the normality test to determine the normality of the data and the homogeneity test to determine the similarity of variants of the data [21]. As for proving the research hypothesis, the increased competence of participants in the optimization of the use of this science kit was measured by the $t$ test with a $95 \%$ confidence level.

\section{RESULTS AND DISCUSSION}

The results of the research are related to the research objectives, where optimization studies can improve the competence of junior high school science teachers in using science kits as a support for scientific learning in Pesisir Selatan. Research data in the form of the results of the pretest and posttest science teachers who take part in the optimization activities provide an illustration of the extent to which the competence of science teachers increases in the use of science kits to support scientific learning. This data is then analyzed statistically to determine the increase in the competence of teachers from the comparison between after and before the treatment. Science teacher competence before optimization is determined from the pretest, and science teacher competence after optimization is determined from the posttest. The results of descriptive statistical analysis of the pretest and posttest using SPSS 20 software are available in Table 2.

Table 2. Results of the Science Teacher Pretest and Postest Statistical Analysis

\begin{tabular}{ccc}
\hline Descriptive Statistic & \multicolumn{2}{c}{ Score } \\
\cline { 2 - 3 } & Pretest & Posttest \\
\hline Number of participants & 20 & 20 \\
Minimum & 20 & 45 \\
Maximum & 50 & 90 \\
Range & 30 & 45 \\
Ideal score & 100 & 100 \\
Mean & 38,25 & 67,50 \\
Median & 40,00 & 70,00 \\
Std.Deviation & 9,072 & 12,927 \\
Variance & 82,303 & 167,105 \\
\hline
\end{tabular}

From the results of the descriptive analysis of the pretest and posttest scores of 20 science teachers, it can be explained that the minimum pretest score is 20 , the maximum score is 50 , and the average score achieved is 38.25 from the ideal score of 100 .

After the treatment, the minimum posttest score was 45 and the maximum score was 90 and the mean score achieved was 67.50 with an ideal score of 100. Standard deviation for the pretest and posttest were 9.072 and 12.927, respectively. From the results of this descriptive statistic, it is known that the posttest mean score is higher than the pretest score. The characteristics of the data group were determined from the normality test and the homogeneity test of the sample data. The results of data normality are as in Table 3.

Table 3. Data Normality Test Results

\begin{tabular}{cccc}
\hline & \multicolumn{3}{c}{ Shapiro-Wilk } \\
\cline { 2 - 4 } & Statistic & df & Sig. \\
\hline Pretest & 0,924 & 20 & 0,121 \\
Posttest & 0,956 & 20 & 0,462 \\
\hline
\end{tabular}


From the normality test using the Shapiro-Wilk test in Table 3, it was obtained the pretest results with a significance of 0.121 and the posttest results with a significance of 0.462 . The significance value for the pretest and posttest is greater than the value $\square=0,05$ So that the results of the pretest and posttest are both normally distributed. The results of data homogeneity for the pretest and posttest can be seen in Table 4.

Table 4. Data Homogeneity Test Results

\begin{tabular}{cccc}
\hline Levene Statistic & df $_{1}$ & df $_{2}$ & Sig. \\
\hline 2,964 & 1 & 38 & 0,093 \\
\hline
\end{tabular}

From the results of the homogeneity test, the significance value is 0.093 . The F value of this analysis result is greater than the value of $\square=0,05$, so it can be stated that the data distribution is homogeneous. Based on the results of the normality test and homogeneity test, it can be stated that the pretest and postest data are normally distributed and the data have the same variance. The statistical test that is suitable for this data is the t test with a 95\% confidence level [22]. The results of the analysis can be seen in Table 5.

Table 5. One-Sample Test

\begin{tabular}{ccccc}
\hline & \multicolumn{4}{c}{ Test Value $=\mathbf{1 0 0}$} \\
\cline { 2 - 5 } Pretest & $\mathbf{t}$ & df & Sig. (2-tailed) & Mean Difference \\
\cline { 2 - 5 } Posttest & $-30,440$ & 19 & 0,000 & $-61,750$ \\
& $-11,244$ & 19 & 0,000 & $-32,500$ \\
\hline
\end{tabular}

Based on the results of the $t$ test on the pretest and posttest values in Table 5, the results obtained a significance of 0.000 . This significance value is in the area of $\mathrm{H}_{0}$ rejection so that the working hypothesis is accepted. From these results it can be explained that the activities of optimizing the use of science kits to support scientific learning have a significant effect on increasing the competence of science teachers, where the post-test results are better than the pretest results. The comparison of the pretest and posttest scores in this optimization activity can be shown in Figure 2.

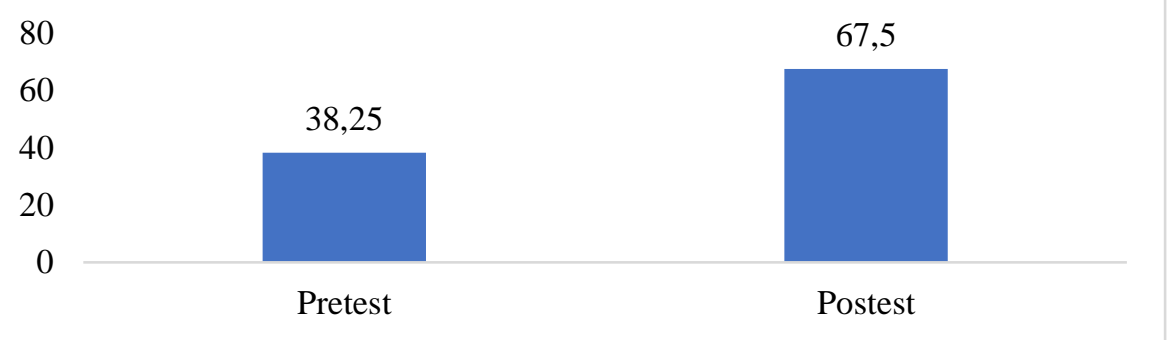

Figure 2. Comparison of Pretest and Posttest Scores.

Based on Figure 2, it can be seen that the posttest average score is higher than the pretest average score. The science teacher pretest average score was 38.25 , while the science teacher posttest average score was 67.50. The percentage increase in teacher competence in using science kits is $29.25 \%$. This means that the activity of optimizing the use of science kits for science teachers is effective in increasing the competence of science teachers. The competencies referred to are pedagogical competences and professional competences. Through this research, science teachers have been able to achieve two of the four main teacher competencies as stated in Law Number 14 of 2005 concerning Teachers and Lecturers. The four competencies are pedagogical competence, personality competence, social competence, and professional competence [23]. 
The results of this study are very relevant to the results of similar research conducted by Prasetyowati, et al regarding the training on the use of science kits for junior high school science teachers in Kalasan District, Sleman Regency, which explains that after optimizing activities, junior high school science teachers can maximize the utilization of science kit to implement the 2013 curriculum in junior high school science learning [24]. In addition, the activity of optimizing the use of this science kit is very useful for science teachers to design appropriate science learning with a scientific approach, with steps of observing, asking, trying, analyzing and communicating [25].

Based on the results of data analysis, it can be seen that after the implementation of optimizing the use of science kits, science teachers in Pesisir Selatan have been able to use science kits properly to support scientific learning in schools. This can be seen from the increase in the competence of science teachers after optimization activities. Recent research conducted by Rapi obtained relatively similar results, that the media science kit training could increase the professionalism of science teachers in Buleleng regarding science kits. Training activities can increase the participants' knowledge and skills about the media science kit. This is based on the average score achieved by the participants, which is 80.9 , in the good category. The response of the participants was very positive and they were very enthusiastic about participating in the training [26].

There are several factors that can improve the competence of science teachers through optimizing the use of kits. First, the material debriefing provided during the optimization activities is in accordance with the needs of the science teacher. This suitability is seen from the very relevance of the material to the needs of science teachers in teaching, and the material provided is also 'up to date' in accordance with the development of the applicable curriculum in schools.

Second, the science kit is one of the main science learning media and is completely available in each school, but the science teacher's ability to use some of the kit equipment is still lacking. With this optimization activity, the teacher becomes more enthusiastic and motivated to learn the kit. With the increase in the ability of teachers to use this science kit, it is hoped that students will also be able to operate the science kit in practicum activities. Science kit is an effective tool in increasing the competence of students in reading objects and events, applying science concepts in nature, and solving relevant problems [24][27].

Third, in this science kit optimization activity, teachers are actually trained in using a science kit by special technicians who are reliable and experienced in practicing the use of this kit. Science teachers are not only trained to use the kit, but are also given skills in recognizing each component of the kit, calibrating the scale of the tool correctly, analyzing experimental data correctly, and arranging and storing the tools for the practicum kit correctly. In addition to these skills, science teachers are also trained on how to produce practicum teaching materials in the form of worksheets based on the science kit experiments conducted. The result was that science teachers were able to produce quality student worksheets. This science worksheet is in accordance with the steps of the scientific approach, there are activities to observe, ask, try, reason and communicate [28]. Through the activities of optimizing the use of this science kit, science teachers have better competence in designing science learning in accordance with the scientific approach, so that there are no more limitations in carrying out practicum activities [29].

The media science kit is very appropriate to support science learning, because in the media science kit there are various kinds of tools for students to do practicum in order to gain direct learning experience so that learning objectives can be achieved properly. Science teachers who have participated in this optimization activity are also expected to 
be able to train students in using the kit correctly. Furthermore, by using the science kit properly and correctly, it means that a science teacher has been able to develop the thinking power, curiosity, and creativity of students according to the physical and psychological development of students [26] [30].

\section{CONCLUSION}

Optimizing the use of science kits can improve the competence of science teachers in using science kits to support scientific learning. Based on the results of data analysis and discussion, it was found that the post-test average score was higher than the pretest average score. The science teacher pretest average score was 38.25, while the science teacher posttest average score was 67.50. The percentage increase in teacher competence in using science kits is $29.25 \%$.

\section{REFERENCES}

[1] M. Huda, Cooperative Learning ( Metode, Teknik, Struktur dan Model Penerapan), vol. 2011, no. Cetakan 1. Yogyakarta: Pustaka Pelajar, 2011.

[2] Fitriyani, "Project Based Learning: The Effect On Student's Science Processes Skills In Tanggamus," Indones. J. Sci. Math. Educ., vol. 1 No.3, pp. 243-253, 2018.

[3] Trianto, Model Pembelajaran Terpadu, no. 15480003. Jakarta: PT Bumi AKsara, 2012.

[4] Hosnan, Pendekatan Saintifik dan kontekstual dalam Pembelajaran. Jakarta: PT Ghalia Indonesia, 2016.

[5] N. Alamsyah, "Penerapan Pendekatan Saintifik Untuk Meningkatkan Kreativitas Dan Hasil Belajar Siswa Dalam Mata Pelajaran IPA," J. Pendidik. (Teori dan Prakt., vol. 1, no. 1, p. 82, 2017, doi: 10.26740/jp.v1n1.p82-96.

[6] Kemendikbud, Pendekatan scientific (ilmiah) dalam pembelajaran. Jakarta: pusbangprodik, 2013.

[7] N. Rustaman, Materi dan Pembelajaran IPA di SD. Jakarta: Universitas Terbuka, 2011.

[8] M. P. Freedman, "Relationship among Laboratory Instruction, Attitude toward Science, and Achievement in Science Knowledge," J. Res. Sci. Teach., vol. 34, no. 4, pp. 343-357, 1997, doi: 10.1002/(SICI)1098-2736(199704)34:4<343::AIDTEA5>3.0.CO;2-R.

[9] Menteri Pendidikan Nasional, Permendiknas No 23 Tahun 2006 Tentang Standar Kompetensi Lulusan untuk SAtuan Pendidikan Dasar dan Menengah. 2006.

[10] Permendiknas No 22 Tahun 2006, "Permendiknas no 22 tahun 2006 tentang Standar Isi," Chest, vol. 25, no. 1, pp. 1-14, 2006.

[11] Rosnita, "Keterampilan guru dalam melaksanakan praktikum dengan menggunakan Komponen Instrumen Terpadu (KIT) IPA SD," J. MIPA-FKIP Univ Tanjungpura, vol. 21, no. 1, pp. 103-106, 2016.

[12] E. Satria, "Pendekatan Lingkungan Dengan KIT IPA Seqip Untuk Peningkatan Keterampilan Proses Ilmiah Dan Hasil Belajar Kognitif Siswa,” J. Akrab Juara, vol. 3, no. 1, pp. 40-60, 2018.

[13] E. Lewis, D. Baker, N. Bueno Watts, and M. Lang, "A professional learning community activity for science teachers: How to incorporate discourse- rich instructional strategies into science lessons," Sci. Educ., vol. 23, no. 1, pp. 1-9, 2014.

[14] N Triningsih, Pembelajaran IPA Di SD, vol. 53, no. 9. 2011.

[15] Zulhelmi, "Kemampuan Guru-Guru Sekolah Dasar dalam Pemgembangan KIT IPA 
Sederhana Berbasis Alam Sekitar Se Kecamatan Inuman,” J. Geliga Sains, vol. 5, no. 2, pp. 125-132, 2017.

[16] E. \& S. Mamang Sangadji, Metodologi Penelitian. 2010.

[17] S. Suryabrata, Psikologi Pendidikan. Jakarta: PT. Raja Grafindo Persada, 2011.

[18] J. W. Creswell, "Research Design: Qualitative, Quantitative and Mixed Methods Approaches,4 Edition," London: Sage, London, 2014.

[19] Sugiyono, Metode Penelitian Kuantitatif, Kualitatif, dan R\&D. Bandung: Alfabeta, 2017.

[20] Sugiyono, Metode Penelitian Pendidikan Pendekatan Kuantitatif, Kualitatif dan $R \& D$. Alfabeta: Bandung, 2014.

[21] D. Nuryadi, dasar-dasar Statistik Penelitian. Sibuku Media, Yogyakarta, 2017.

[22] K. E. Meyer, A. Van Witteloostuijn, and S. Beugelsdijk, "What's in a p? Reassessing best practices for conducting and reporting hypothesis-testing research," J. Int. Bus. Stud., vol. 48, no. 5, pp. 535-551, 2017, doi: 10.1057/s41267017-0078-8.

[23] Pemerintah Indonesia, "Undang-Undang Nomor 14 Tahun 2005 tentang Guru dan Dosen," in Sekretariat Negara, 2005, pp. 60-61.

[24] Prasetyowaty, "Training on the Use of SMP KIT Tool for Junior High School Teachers Kalasan District of Sleman Regency to Support Teaching and Learning Activities (KBM) in Implementing Curriculum 2013," J. Pengabdi. Masy. MIPA dan Pendidik. MIPA, vol. 2, pp. 100-103, 2018.

[25] M. Zahra, "SETS Learning (Science, Environment, Technology, Society): The Effect On Science Process Skills," Indones. J. Sci. Math. Educ., vol. 02 (3), pp. 320 327, 2019.

[26] Rapi, "Pelatihan Media KIT bagi Guru-guru SMP di kabupaten Buleleng," 2020.

[27] E. Satria, "Penggunaan Alat Peraga Dan KIT IPA Oleh Guru dalam Pembelajaran Di Beberapa Sekolah Dasar Di Kecamatan Padang Utara dan Nanggalo Kota Padang," IKRAITH-Humaniora, vol. 2 NO.2, 2018.

[28] H. Susilana, Rudi \& Ihsan, "Pendekatan Saintifik Dalam Implementasi Kurikulum 2013 Berdasarkan Kajian Teori Psikologi Belajar,” Edutech, vol. 1, 2013, [Online]. Available: file:///C:/Users/User/Downloads/3095-5640-1-SM.pdf.

[29] M. Ahied, "Improving Students' Scientific Literacy Through Distance Learning With Augmented Reality-Based Multimedia Amid The Covid-19 Pandemic," J. Pendidik. IPA Indones., vol. 9 (4), pp. 499-511, 2020.

[30] Safaruddin, "The Effect Of PjBL With WBL Media And Cognitive Style On Students' Understanding And Science-Integrated Concept Application," $J$. Pendidik. IPA Indones., vol. 9 (3), pp. 384-395, 2020. 